\title{
Mining and geological knowledge during the Neolithic: a geological study on the variscite mines at Gavà, Catalonia
}

\author{
1 Centro de Geociencias, Universidad Nacional Autónoma de México. Carretera Qro.-S.L.P. km 15.5, Campus UNAM-Juriquilla, 76230 Santi \\ ago de Querétaro, Mexico. \\ 2 Departament de Cristal-lografia, Mineralogia i Dipòsits Minerals. Facultat de Geologia. Universitat de Barcelona. Martí i Franquès s/n, 08028 \\ Barcelona (Catalonia), Spain. \\ 3 Institut für Geologie, Mineralogie, und Geophysik, Ruhr-Universität Bochum, 44780 Bochum, Germany. \\ 4 Museu de Gavà, Plaça Dolors Clua 13-14, 08850 Gavà (Catalonia), Spain. \\ 5 Institute of Geology, Komi Science Centre, Russian Academy of Sciences, Ural Division. 54 Pervomaiskaya St., 167610 Syktyvkar (Komi \\ Rep.), Russian Federation.
}

The Gavà Neolithic Mining Complex (GNMC) near Barcelona was active during the Neolithic age, since ca. 6000 BP until about 700 years after. These mines show up to five different underground mining levels, developed as galleries and chambers, communicated through pits, drawing a complex network with a total known length of over $1000 \mathrm{~m}$. These are some of the oldest underground mines in Europe but, contrary to the rest of the mine workings known of the same epoch, this is the only mining complex reported to date whose aim was not mining for conventional substances for the epoch such as chert, ochre or copper. The main aim of the GNMC was variscite, a green phosphate mineral similar to turquoise that can be easily cut and polished to make ornaments such as necklaces or bracelets. This paper is focused mainly on the geological mapping and examination in surface and underground exposures of the different phosphate mineralization types (stratabound and veins) and other relevant geological features such as discordances, thrusts, faults, and folds.

\section{Introduction}

During the 1970-80 decade, in the Gavà village (20 km southwest from Barcelona, Figure 1) a mining complex was found in the Can Tintorer area (named here Gavà Neolithic Mining Complex, or GNMC), consisting of pits and galleries with a total length of over $1000 \mathrm{~m}$, although the archaeological excavation of the area is still in process. This complex was active for about 700 years during the Neolithic age, from about ca. 6000 BP (Alonso et al., 1978; Villalba et al., 1990). Thus, these are some of the oldest underground mines in Europe, and the only ones of that age whose main mining aim was not chert (flint) or copper to make bronze. According to Villalba et al. (1987 and 1989), the mining was aimed at chert, ochre and variscite, although this question has been matter of discussion among archaeologists for some time (Fernández-Turiel et al., 1990; Bosch et al., 1993). Chert and hematite were important aims for min- ing during the Neolithic, and even during the Paleolithic in Egypt and Swaziland (Dart and Beaumont, 1967; Vermeersch et al., 1984; Vermeersch and Paulissen, 1989; Bednarik, 1992). However, based on geological evidence, Costa et al. (1994) determined that the aim for mining in the GNMC was exclusively variscite, and that cherts would have eventually been extracted to as a byproduct for toolmaking. Although mining for chert during the Neolithic was common in Europe at that time (see Bosch, 1979; Rudebeck, 1987; Galiberti et al., 1991; Bostyn and Lanchon, 1992; Haas and H.mor, 2002), the examination of Costa et al. (1994), expanded in this paper, demonstrates that only extensive mining for variscite is congruent with the extent and structure of the mines in the GNMC. Variscite is a sightly green phosphate mineral, similar to turquoise, which can be easily cut and polished to make ornaments such as necklaces or bracelets. Mining during Prehistoric times for materials other than those specifically used to elaborate tools did not occur again until some centuries later, during the expansion of trade with amber from the Baltic Sea area.

In 1994, the development of archaelogical excavations in the GNMC revealed about $400 \mathrm{~m}$ of galleries and three mining levels. As the archaelogical excavations have not stopped since then, more than $1000 \mathrm{~m}$ of galleries and five mining levels have been exposed so far, both in the GNMC and adjacent areas (Can Badosa), and it is

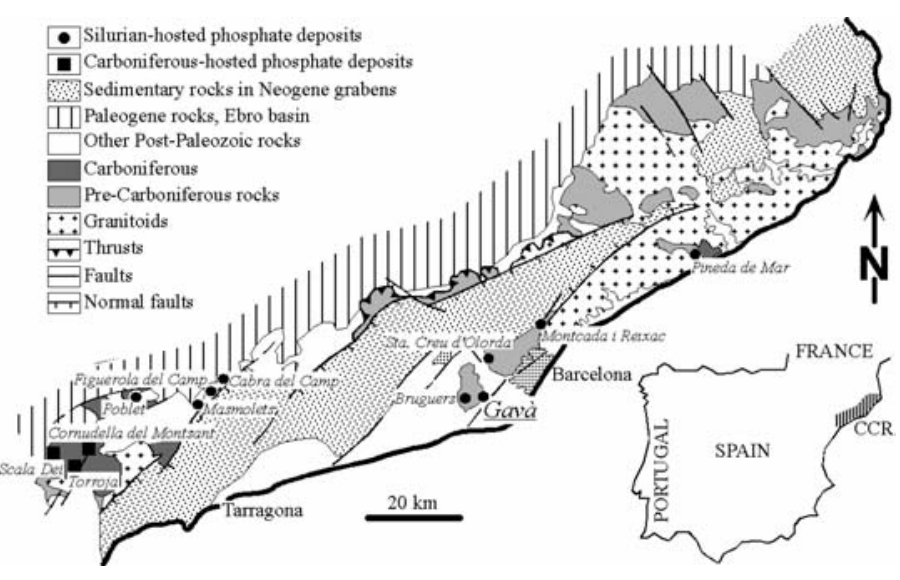

Figure 1 Geological map of the Catalonian Coastal Ranges (CCR), modified from Julivert and Duran (1990), with the location of the main deposits and showings of $\mathrm{Fe}-\mathrm{Al}-\mathrm{Cu}$ phosphates hosted by Paleozoic rocks. 
thought that the total extent of the mining complex is much larger. Thus, it is necessary to update the previous works in the light of the newly revealed mining operation. The GNMC comprises over 80 mines, although it is possible that many others are covered by modern housing. The located mines comprise fully excavated mines, showing dimensions from a few metres to about $200 \mathrm{~m}$, mines still under archaeological excavation, and mines whose excavation has not initiated yet. We selected three mines that have been more fully excavated or which show the highest potential development of mining. These mines show up to five different mining levels, developed as galleries and chambers, which communicated through pits. One of the mines is found under the Can Tintorer house, and the other two (named $J$ and $L$ ) are located in the present archaeological area in a field adjacent to the house. In addition, we describe the Neolithic mine recently discovered close to the GNMC, in the Can Badosa area.

\section{Geological setting}

The phosphate deposits of the area are hosted in Paleozoic rocks (Julivert and Duran, 1990; Melgarejo, 1992; Figure 1) deformed during the Hercynian orogeny. They consist of (1) shales, graywackes and quarzites attributed to the upper Ordovician or lower Llandovery; (2) black shales with graptolites, phosphate and chert layers, lower Llandovery; (3) black shales with graptolites and pyrite nodules, middle Silurian; (4) limestones and dolostones with orthocera and crinoidea, upper Silurian-lower Devonian; (5) marls with tentaculites, middle Devonian; and (6) green shales and graywackes with Dictyodora, lower Carboniferous. The Hercynian deformation produced at least two groups of coaxial folds and two late thrusting generations. The whole is discordantly overlain by the Triasic Germanic Facies.

The geology of the GNMC consists of Lower Silurian grey shales (Figure 2), with (1) chert in layers with variable thickness, that may be slumped, or in nodules that may attain several $\mathrm{cm}$ in diameter, (2) massive iron oxide layers, mainly hematite, (3) layers with monomineralic nodules of nontronite, (4) layers of massive jarosites, and (5) layers of $\mathrm{Fe}-\mathrm{Al}$ phosphate minerals and apatite (Costa et al., 1993; Camprubí et al., 1994). The gray shales are constituted by $\mathrm{Ba}$ and $\mathrm{V}$-rich white micas and contain abundant disseminated rutil, pyrite, chalcopyrite, barite and monazite.

The remobilization processes of stratabound mineralizations, especially phosphates, occurred either before, during, and after the Hercynian deformation, and resulted in the formation of numerous phosphate veinlets. The most important period for veinlet formation is post-Hercynian (post-schistosity), as these are the most abundant in volume in the area. These veinlets are formed by variscite $\left(\mathrm{AlPO}_{4} \cdot 2 \mathrm{H}_{2} \mathrm{O}\right)$, strengite $\left(\mathrm{FePO}_{4} \cdot 2 \mathrm{H}_{2} \mathrm{O}\right)$, turquoise $\left(\mathrm{CuAl}_{6}\left(\mathrm{PO}_{4}\right) 2(\mathrm{OH})_{5} \cdot \mathrm{H}_{2} \mathrm{O}\right)$, and jarosite $\left(\mathrm{KFe}^{3+}{ }_{3}\left(\mathrm{SO}_{4}\right)_{2}(\mathrm{OH})_{6}\right)$, and have a preferential SSW-NNE orientation.

The above materials are discordantly overlain by Quaternary caliche and clay layers, up to $3 \mathrm{~m}$ thick, and Quaternary debris.

\section{Phosphate mineralization types}

In the GNMC have been determined two phosphate mineralization types: stratabound layers and late veinlets. The phosphate stratabound layers are interbedded with gray shales of the lower Llandovery. The following series (Figure 2) was determined in the $L$ mine of the GNMC: (1) alternating $\mathrm{dm}$-thick layers of gray shales and cherts (generally slumped), up to $1.5 \mathrm{~m}$ thick in section; the chert layers, generally slumped, grading thinner upwards; (2) gray shales with occasional thinner chert layers, and minor mm-thick phosphate layers, up to $1 \mathrm{~m}$ thick; (3) gray

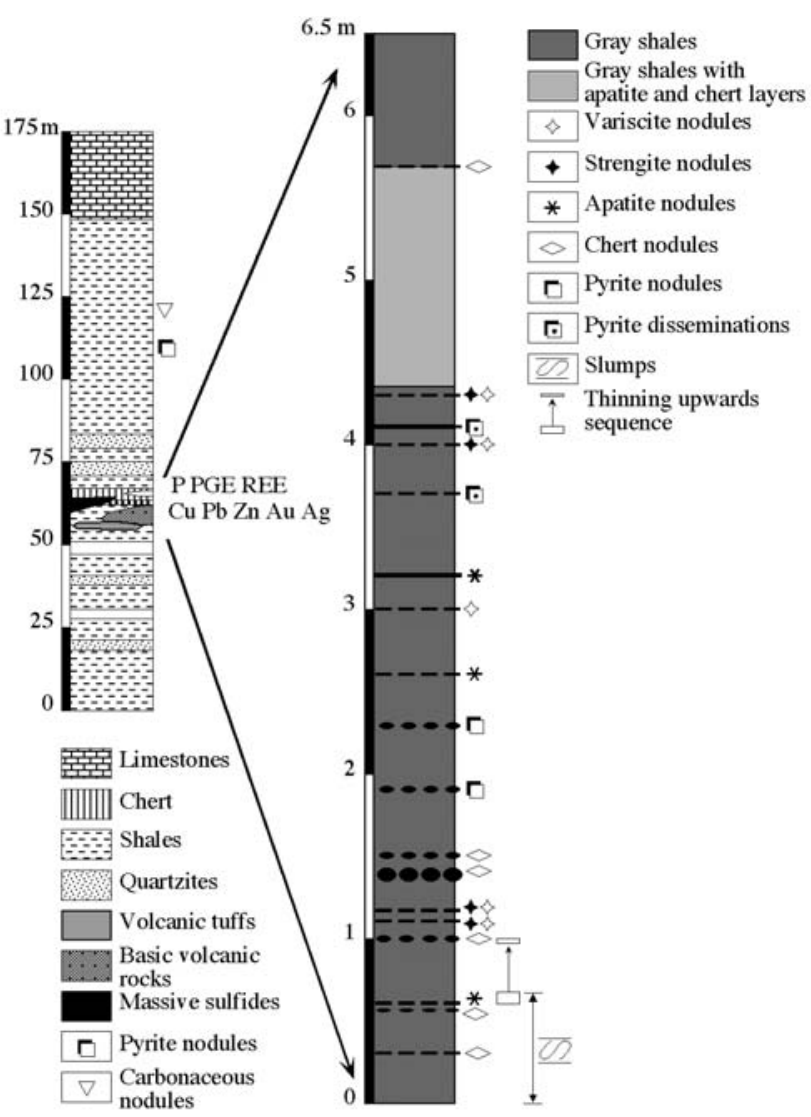

Figure 2 Detailed stratigraphic section of Silurian shales in the Gavà Neolithic Mining Complex (right), limited to the general stratigraphical section of the central part of the Catalonian Coastal Ranges, or CCR (left). In the latter is indicated the position of the main elements that form significant deposits in the CCR.

shales with large chert nodules (diameter up to $50 \mathrm{~cm}$ ) and mm-thick phosphate layers, up to $1.5 \mathrm{~m}$ thick; (4) shales with very scarce chert and phosphate layers, up to $2 \mathrm{~m}$ thick; and (5) alternations of cherts and shales with local thin apatite layers, up to $1.5 \mathrm{~m}$ thick.

The phosphate layers observed in the $L$ mine are stratabound, essentially monomineralic, very fine grained, and between $1 \mathrm{~mm}$ and some $\mathrm{cm}$-thick. They consist generally of apatite or variscite, although some layers are constituted by strengite or phosphosiderite. In the Can Tintorer mine, the stratigraphical section has significant differences from the section described above, as the unit of gray shales with large chert nodules is overlain by a massive hematite layer (Figure 3), up to $1 \mathrm{~m}$ thick, which is interlayered with brown

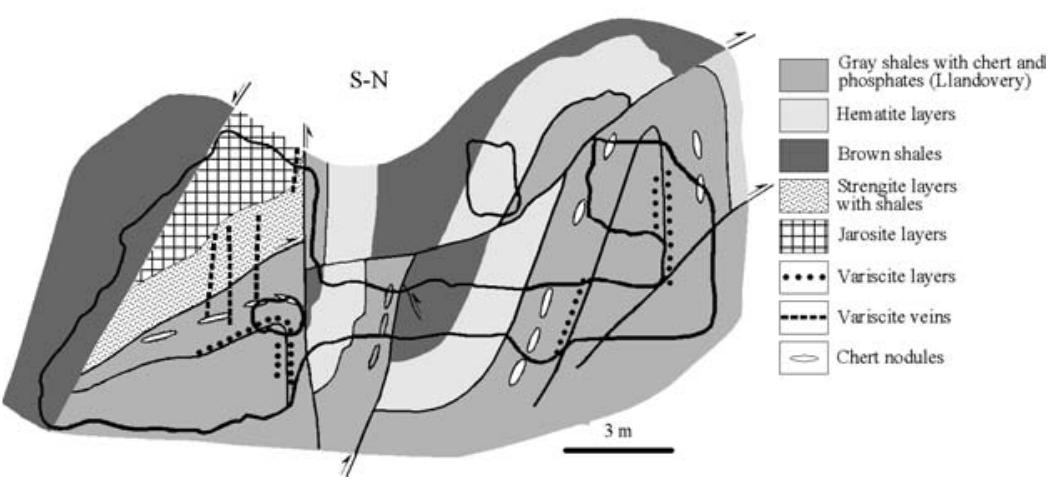

Figure 3 Geological section in the lower mining level of the Can Tintorer mine of the Gavà Neolithic Mining Complex (GNMC). Note the development of a chamber in the zone with the highest abundance of phosphate veinlets, and the gallery passing through a chert-rich layer with no specific mining on it. 
shales. The latter becomes dominant upward. Thus, it is possible that the phosphate-rich section corresponds laterally to the iron oxiderich section. In addition, there are also thin nontronite layers interbedded within the shales. In the Can Tintorer mine, the phosphate-rich section is $50 \mathrm{~cm}$ thick and consists of strengite or phosphosiderite layers. It is overlain by a massive primary jarosite bed, up to $40 \mathrm{~cm}$ thick.

The late veinlet mineralization is abundant in the study area. Although some veinlets in neighboring areas show evidence of ductile deformation (some are clearly contemporaneus to schistosity and have the same mineralogy of post-schistosity mineralization), the dominant veinlet mineralization in the GNMC is undeformed and was produced long after the Hercynian deformation. The veinlets are generally monomineralic, and may contain $\mathrm{Fe}-\mathrm{Al}-$ phosphates or Ca-phosphates as two different veinlet types, and filled diaclases with dominant $\mathrm{N}-\mathrm{S}$ or NE-SW orientations. Some veinlets show features resembling hydraulic brecciation. These veinlets are usually 1 to $5 \mathrm{~mm}$ thick, up to $3 \mathrm{~cm}$.

The $\mathrm{Fe}-\mathrm{Al}$-phosphate veinlets are formed by variscite, strengite or phosphosiderite or, less commonly, turquoise. The electron probe microanalyses on the minerals of these veinlets (Camprubí et al., 1994) do not show significant chemical variations with respect to the same species found in the stratabound mineralization. The slight content of some trace elements $(\mathrm{Cr}, \mathrm{V})$ of phosphate minerals of this association may be due to leaching of host shales, which are relatively rich in these elements. The phosphate minerals of this association are frequently associated with jarosite and alunite. All these minerals are texturally microcrystalline and, locally, spherulitic due to a slight increase in crystal size, indicating some degree of recrystallization in the veinlets. Frequently, it was observed that this recrystallization progressed from tiny cracks in the mineralization or from the contact with host rocks. In the Can Badosa mine, away from the area of GNMC, variscite was seldom found associated with quartz in veinlets.

The Ca-phosphate veinlets formed later. Montgomeryite $\left(\mathrm{Ca}_{4} \mathrm{MgAl}_{4}\left(\mathrm{PO}_{4}\right)_{6}(\mathrm{OH})_{4} \cdot 12 \mathrm{H}_{2} \mathrm{O}\right)$ partially filled some fractures in the shales. These veinlets show irregular morphologies and orientations. Montgomeryite is displayed as micron-sized individual platy crystals, or as radial aggregates there of, commonly directly implanted on the fracture gauge or on goethite film-like coatings. Crandallite $\left(\mathrm{CaAl}_{3}\left(\mathrm{PO}_{4}\right)_{2}(\mathrm{OH})_{5} \cdot \mathrm{H}_{2} \mathrm{O}\right)$ is microcrystalline, and is found in veinlets or replacing phosphates of the $\mathrm{Fe}-\mathrm{Al}$ association. The latter occurred from tiny cracks in the $\mathrm{Fe}-\mathrm{Al}$ phosphate veinlets or from the contact with host rocks.

\section{Origin of phosphate mineralizations}

The phosphate stratabound mineralizations are good guide beds for the bottom of the Silurian in the region. Appropriate conditions for the biochemical precipitation of phosphates apear to have been absent. We, therefore, suggest a primary exhalative genesis of the primary phosphate deposits (apatite-rich layers), based on the following evidence:

1. the phosphate mineralizations are stratabound, hosted in submarine sediments, and prior to the Hercynian deformation;

2. the phosphate minerals are stratigraphically associated with levels with a mineralogy that can be interpreted as exhalative, with the formation of chert, hematite, nontronite, jarosite;

3. these deposits are associated with positive anomalies of $\mathrm{V}$, $\mathrm{Ba}, \mathrm{Cu}$ and rare earth elements;

4. these deposits are contemporaneous with basic alkaline volcanism (not present in the area, but located in other spots of the Catalonian Coastal Ranges), and with massive sulfide deposits hosting $\mathrm{Zn}-\mathrm{Cu}-\mathrm{PGE}$ mineralizations with interbedded apatite layers (Melgarejo et al., 1994, Alfonso et al., 2002). The close association of phosphate minerals with jarosite and hematite suggests that their deposition occurred from very acid and oxidizing fluids.
Subsequently, the apatite-rich layers would have been partially replaced by $\mathrm{Al}$ - and Fe-phosphates after fluids of undetermined source, either hydrothermal or meteoric, that leached $\mathrm{Fe}$ and $\mathrm{Al}$ from host shales. Also, in the Silurian strata there are abundant levels with disseminated pyrite that could provide the necessary sulfate anionic groups to carry metals in solution. The close association of phosphate stratabound layers with barite-rich shales may be congruent with this explanation, as barite is not primary and may result from the fixing of sulfate derived from disseminated sulfides, and $\mathrm{Ba}$ released after weathering or hydrothermal alteration of Ba-rich muscovite, a widespread mineral in the series. The direct exhalative formation of $\mathrm{Fe}$ - and Al-phosphates may be a geochemic cause(see Nriagu, 1972, and Stumm and Morgan, 1981), but in this case, the possibility of a formation of the stratabound $\mathrm{Fe}$ - and Al-phosphate mineralization after replacement of apatite-rich layers is more plausible.

The stratabound phosphate mineralizations can be, in turn, easily remobilized by any type of oxidizing solution, either hydrothermal or meteoric. As an analogous argument to explain the formation of phosphate-rich stratabound layers, the leaching of pyrite from the series would provide the acid and oxidizing solutions necessary to mobilize phosphorus from the series. The P-rich solutions would circulate through fractures or other pores, and deposit secondary phosphates, the composition of which depends on the composition of host rocks in the GNMC, triggered by faulting. Thus, $\mathrm{Fe}-\mathrm{Al}$ phosphates form from $\mathrm{Fe}$ - and $\mathrm{Al}$-rich rocks and, eventually, turquoise may form from leaching of disseminated chalcopyrite. The association of phosphates with alunite or jarosite, and the composition of phosphates itself, provide evidence for the precipitation of phosphates in acidic and oxidizing environments. As in the Can Badosa mine some veinlets show variscite associated with quartz, it may be argued that at least part of this type of mineralization may have been originally hydrothermal.

An alunite sample from late phosphate veinlets of the GNMC yielded a $\mathrm{K}-\mathrm{Ar}$ age of $1.20 \pm 0.05 \mathrm{Ma}$. Another alunite sample from phosphate veinlets with similar mineralogy and in the same geological context from Montcada i Reixac ( $5 \mathrm{~km}$ N of Barcelona, see Figure 1) yielded a $\mathrm{K}-\mathrm{Ar}$ age of $1.33 \pm 0.05 \mathrm{Ma}$.

However, Al-phosphate and sulfate veinlets may also have been formed by recent or ancient meteoric phenomena. Dill et al. (1991) describe a similar deposit in Sudan, demonstrating that the veinlet mineralizations there are Quaternary in age and that have a meteoric origin.

\section{The Can Tintorer mine}

The geological structures shown in this mine display a complex structural pattern: the Silurian rocks were highly deformed during the Hercynian orogeny, accounting for at least two different fold generations with a similar orientation of fold axis (approximately NW-SE) but opposite vergence, cut by several Hercynian thrusts, the development of kink bands, and normal and reverse faults of different ages. As a constant in the whole mining complex, two types of phosphate mineralization were observed (Figure 3): (1) stratabound, consisting of monominerallic layers of strengite, variscite, and apatite; and (2) veinlets, with variscite as the most prominent mineral, but also phosphosiderite and strengite, with associated alunite and jarosite.

In addition, there are levels with large chert (opal) nodules, and monominerallic levels of hematite. These materials were accounted when we evaluated the possible aims for mining, as cherts could have been extracted to make tools, and iron oxides could have been used as ochres for pigmentation.

The Can Tintorer mine comprises two mining levels that are communicated by pits or chambers. The gallery of the upper level, accessible by pits and ramps, essentially follows a thrust surface. Along this gallery, several small workings were done on variscite veinlets oriented $\mathrm{N}-\mathrm{S}$, and also in two pits. One of these pits leads to 


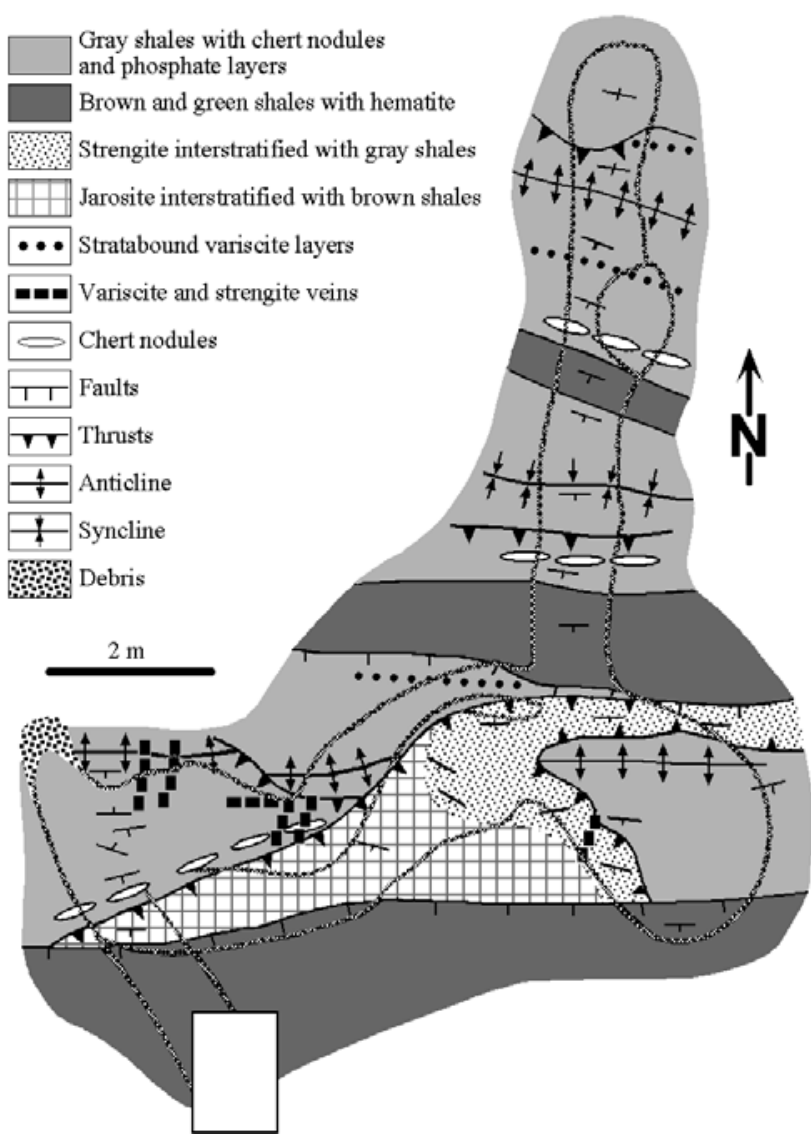

Figure 4 Geological map of the lower mining level of the Can Tintorer mine of the GNMC. The geological section of Figure 3 runs along the main $N-S$ gallery of this level. Note the exploration gallery cutting through chert- and hematite-rich layers, and the chamber developed in a thick stratabound strengite-rich layer and variscite veinlets and stratabound layers. Also note that the main fractures limit the chamber, and the rest of galleries and local mining fronts are determined by occurrence of phosphate veinlets and layers.

a short gallery between the two main mining levels whose only purpose seems to have been to locate the line of the main thrust. The second pit was excavated in order to link the two mining levels. This pit was mined following a stratum containing variscite, that was also found in other parts of the upper gallery. The first metres of the access gallery to the lower level repeatedly cut repetitively the chert and iron oxide layers (Figures 3 and 4), and no evidence has been found that these were specifically mined. There is an incipient pit developed on a chert level, but there is also an associated small layer of variscite, and thus it is uncertain whether this pit was excavated in order to obtain chert or variscite. The access gallery to the lower level leads to a chamber that shows stratabound layers of strengite or variscite, and variscite veinlets. Some galleries were excavated from this chamber that follow stratabound layers of variscite or strengite, and, laterally, some small digs were done on phosphosiderite and strengite veinlets.

Assuming that chert and iron oxides were important objectives for mining, we deduce that some galleries would be expected to follow the geological structures that contain these materials. On the contrary, all the galleries were made ignoring the chert and iron oxide layers, and no mining fronts are found until the phosphate mineralizations were reached by the advance of mining (Figure 4).

The existence of other galleries can be explained by the need to connect the two mining levels or of ventilating the mine, rather than having made to extract material. On the other hand, the fact that chambers and galleries that were mined on barren sections following fracture planes (faults and thrusts, Figures. 3 and 4) can be explained by the economy of effort in digging through materials that can be more easily removed due to fracturing. Moreover, the location of the entrance to the small intermediate level, together with the trace of the lower level, with a small pit that follows the fracture dipping, suggests that the Neolithic miners planned the access to the small intermediate level specifically in order to catch the fracture plane. Thus, it appears that the miners learned about the three-dimensional relations of the structures that were favorable for their purposes.

\section{$J$ and $L$ mines}

In these mines the geological structures are far more simple that in the Can Tintorer mine. Although tight folds with sharp hinges are common, the result of such folding is the consistent repititon of the phosphate layers, that generally dip subvertically. Such structural features make the interpretation of the mining methods simpler. A consistent observation all through these mines is that practically all the chambers and galleries were dug so that they directly followed stratabound layers of phosphate minerals, mainly variscite, and veinlets bearing strengite, variscite, phosphosiderite and jarosite. However, jarosite has no ornamental interest and it may have been rejected when processing the minerals. The average orientation of the phosphate stratabound layers is $120^{\circ}(\mathrm{NW}-\mathrm{SE})$ and the mean orientation of the veinlets is $30^{\circ}$ (NE-SW), which explain the consistent and coincident orientation of the galleries of mines $J$ and $L$ (Figure 5). In addition, this disposition allowed the miners to leave pillers during mining to prevent collapse of the chambers.

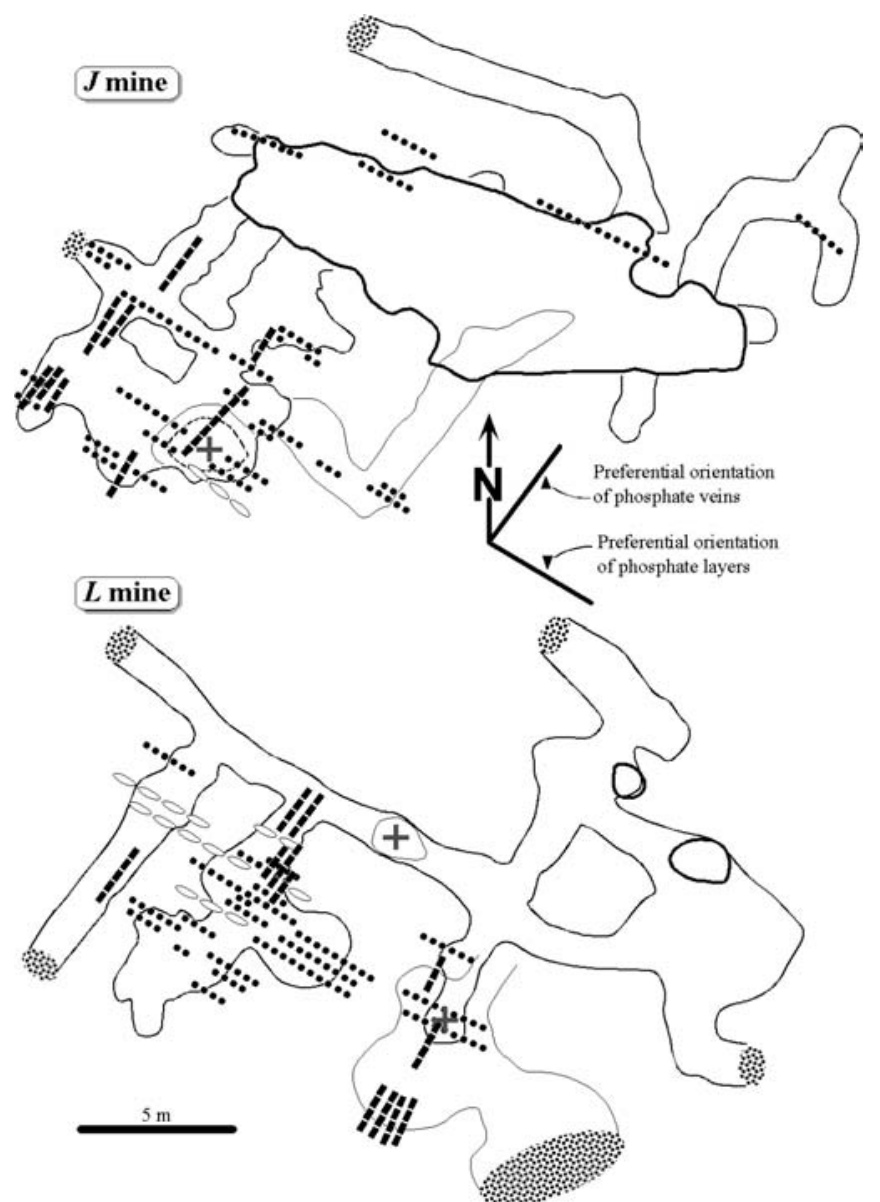

Figure 5 Plans of the $J$ and $L$ mines of the GNMC with the location of the main phosphate-rich veinlets and stratabound layers. Note the concordance of the trace of layers and veinlets with the trace of galleries and chambers, and the occurrence of pillers left behind during mining for stability purposes. The symbols used are the same as in Figure 4. 


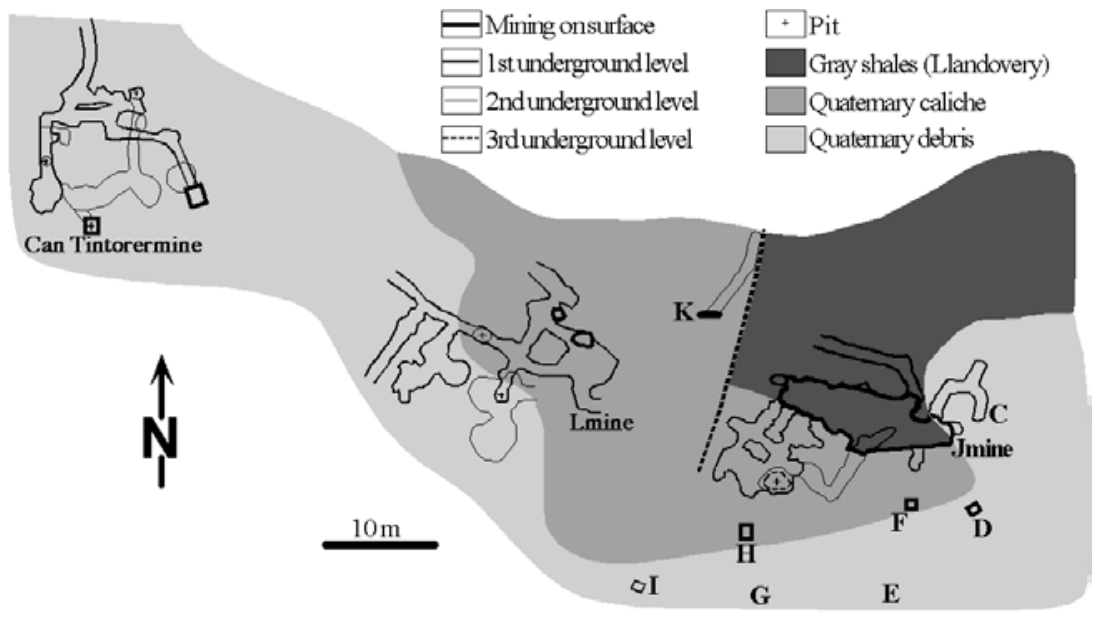

Figure 6 Geological map of the GNMC, showing the plan of the mining levels of the Can Tintorer, $J$ and $L$ mines. The capital letters indicate the locations of mines that are not yet excavated or that are currently under archaelogical excavation.

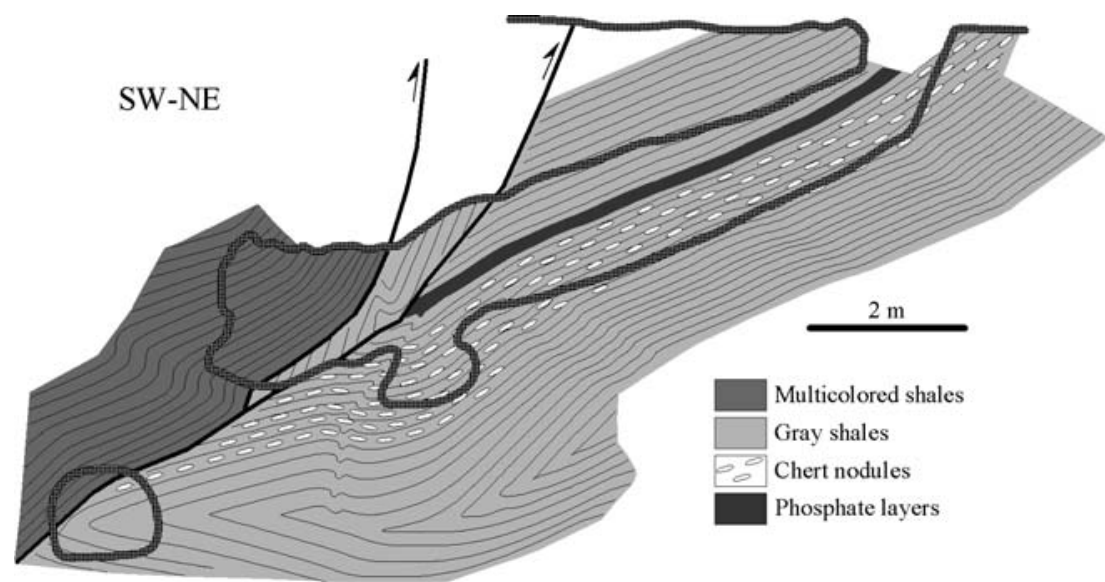

Figure 7 Geologic section following the only access gallery of the main Neolithic mine found in the Can Badosa area, about $500 \mathrm{~m}$ West of the GNMC.

The main gallery of the $L$ mine, however, was developed following a possible strike-slip fault oriented NW-SE. This gallery goes through several metres of barren shales until it met thin veinlets of phosphosiderite and strengite, perpendicular to the fault, and new galleries were started on these veinlets. The subsequent galleries cut the stratabound phosphate mineralization, giving way to the opening of new galleries and chambers. This mine also includes a 5 m-deep pit developed on stratabound layers of variscite (Figure 5). It is important to notice that there is no evidence up to date that, in this region or elsewhere, during the Neolithic there was any ornamental craft work using strengite or phosphosiderite. Some of the galleries of the Mine $L$ were dug on strengite or phosphosiderite veinlets. Thus, we may conclude that the Neolithic miners extracted variscite and left strengite and phosphosiderite in the walls, and that the Neolithic miners acquired precise empirical knowledge about the close association of Al- and Fe-phosphates and/or the two main orientations of the variscite-bearing geological bodies.

On another hand, in this particular area of the mining complex the access pits to the mines were dug on the Quaternary caliches and debris that cover the Silurian rocks (Figure 6). This is another important aspect to account for the 'geological' knowledge during the Neolithic.

Up till now, the $J$ and $L$ mines have not yet been fully excavated by the archaeologists, but five different mining levels are exposed in mine $\mathrm{J}$, at a depth of over $45 \mathrm{~m}$ under the surface. As the archaeo- logical site, as we know it today, was conditioned for the present archaeological excavations and for visits open to the public, part of the Quaternary cover was removed. Also, some of the Quaternary cover was previously removed in modern times to level the area prior to housing developments. Thus, it is easy to think that the original depth of the mining levels under the surface when the mining complex was active was significantly greater. This helps to give an idea of the extent and importance of mining activities in this area, as it is possible that the Neolithic miners had to dig pits through several metres of Quaternary debris and caliche to attain blind mineralized structures.

\section{The Can Badosa mine}

This mine is located about $500 \mathrm{~m}$ West of the GNMC in the outskirts of the Gav $\ddagger$ town. It was recently discovered when the ground was being prepared to build new houses in the area, and it was urgently examined and mapped before impending housing started. In this area several Neolithic mines have been discovered and examined during the last three years, all of them with a much lesser development of mining works than those in the GNMC, and they are less than $15 \mathrm{~m}$ long.

The most interesting mine of this area is the Mine 84, named in this paper as the Can Badosa mine. This mine is interesting when examining the working process of Neolithic miners because it is sure that the mine had only one entrance, and thus it helps to better trace the mining advance, and to know which materials were outcropping before mining started. The host rocks are the same as in the GNMC: gray shales with chert nodules and phosphate layers, and barren brown and multicolored shales. In the Can Badosa mine the access gallery was developed on gray shales (Figure 7) following a phosphate-rich layer that was probably outcropping before mining. Nonetheless, the phosphate-bearing layer is constituted neither by variscite nor strengite, nor any other flaring phosphate mineral. The latter, plus the morphology of the access gallery, suggests that such phosphates were not the aim of the mining. This is also shown in other small mines of the Can Badosa area.

The access gallery deepens through the phosphate layer until a thrust is encountered (corresponding to the third stage of Hercynian deformation). Then, some digging was done on the upper thrust sheet (Figure 7), made up of brown and multicolored shales that do not show any phosphate content. We presume that mining on this sheet stopped for this reason. In this point, the gallery changes its orientation, suggesting that the Neolithic miners had some reason to think that these shales are not favorable to their aims. Then, a small pit of about $50 \mathrm{~cm}$ deep was dug in the chert-rich layers, similar to other mines in the GNMC.

Laterally to the thrust, a mining chamber was dug downward on gray shales, where presumably some variscite-bearing veinlets were mined, as some remains of them are still left on the floor. In this spot, the gallery divides in two: the NW branch follows variscite veinlets and strengite layers, whereas the SE branch follows a barren section of gray shales. The latter leads to a second chamber showing chert nodules, strengite layers and flaring variscite veinlets. This chamber was used as a human burial place and was closed by a gravestone made of limestone. In both mining galleries, all the observed variscite-bearing veinlets were only a few mm-thick, and it may be that this was why the mine was abandoned and used for burial instead. 


\section{Implications for mining techniques during the Neolithic}

According to the present state of archaeological excavations in the GNMC after its geological examination, we discuss the several implications about the knowledge of geological structures, and strategies and techniques applied to mining during the Neolithic.

In the mining galleries, the Neolithic miners followed the variscite-bearing veinlets or stratabound layers with associated strengite or phosphosiderite, and they did not follow the chert or iron oxide levels (Figures. 3, 4, 5 and 7). This indicates that variscite was the main aim for mining, for ornamental purposes. Besides, in several archaeological sites of the Neolithic period in Catalonia, Andorra, and Southern France, only ornaments made up of variscite (mainly necklaces and bracelets) are found. The largest known example of variscite ornaments from Gavà was found in a Neolithic burial site in Cardona (Central Catalonia), where mining for salt-in an outcropping salt dome named Muntanya de Sal, or Salt Mountain, mined until 1990 — was developed simultaneous to mining in Gavà (Weller, 2002). Chert could eventually have been used to make tools, and iron oxides (hematite) could have served to make pigments, but there is no evidence in the excavated mines suggesting that these materials were intentionally mined. These aspects are important to help understand the social and 'economic' situation during the Neolithic. Although we have also found turquoise in an outcrop by the GNMC, there is no direct evidence in the mines, or indirect evidence from the Neolithic sites where variscite ornaments were found, that turquoise was ever mined in this area. It is possible that the occurrence of turquoise in Gavà is merely eventual, or that turquoise veins were not thick enough to produce material for ornaments in contrast to the case of the Cerrillos District in New Mexico where the Native Americans started mining turquoise ca. 1000 AD (Warren and Mathien, 1985).

Some of the galleries of the studied mines were opened following phosphate or sulfate (jarosite) veinlets that did not have any ornamental interest. Thus, it is possible that the Neolithic miners empirically learned about mineral associations, and about minerals associated with certain geological structures that could be used as exploration criteria.

Many galleries follow fractures as thrusts and faults (Figures 3 and 4). These workings could have been undertaken with three possible objectives: first, to obtain new phosphate findings or "reserves" in the easiest way in an active mine, as digging in fractured rocks would imply less effort than mining on mineralized structures themselves; second, to easily excavate wide chambers in the mines; third, to avoid opening new pits through the Quaternary cover (Figure 6), which was a more 'expensive' process in terms of invested effort. The Quaternary cover is generally formed by compact caliche and debris up to $\sim 2 \mathrm{~m}$ thick without profitable discontinuities that would facilitate digging with stone tools. In addition, during the Neolithic this cover was probably much thicker than today, as the present surface resulted from the removal of part of the Quaternary cover both to level the terrain for housing in modern times and to condition the area for archaeological excavation and for hosting visitors. Besides, the Quaternary cover is barren and hides the phosphate-bearing rocks, which means that digging every single new pit carried the risk that no mineralization was found.

Due to the drastic changes in the local landscape from the Neolithic up to the present, there is no direct evidence of how mining for variscite started. However, the first mines would have been done on outcropping phosphate-bearing Silurian shales, as there are still many outcrops of these rocks in the area, despite the extensive housing in Gavà. As the only way to enter some of the most important mines in the GNMC is by pits dug directly through the Quaternary cover (Figure 6), the Neolithic miners must have realized that the phosphate-bearing gray shales were concealed at a relatively shallow depth by the Quaternary cover. That realization led them to start digging pits directly on the cover. This suggests that the Neolithic min- ers acquired enough empirical geological knowledge to understand the morphological significance of a discordancy, regardless of its genetical significance. This agrees with the arguments of Bednarik (1992), obtained in a very different geological setting and type of mining complex, who summarized the technological and cognitive requirements for subterranean mining, writing that: “...the evidence seems to suggest, in some cases, that they [the Prehistoric miners] were capable of predicting the occurrence and spatial extent of a ... concealed geological feature. While it may be cognitively easy to follow an exposed seam, it is quite a different matter to undertake a calculated course of action that promises no immediate reward, and whose eventual reward is based entirely on the validity of an abstract prediction".

The present study suggests that the Neolithic miners probably recognized and simple three-dimensional geological structures (tabular bodies, as fractures and the stratigraphic discordance between the Silurian gray shales and the Quaternary caliches, clay deposits and debris), and used these observations to plan new mines and/or to search for new resources.

There is sufficient evidence that the Neolithic miners formed their own idean about which rocks were favorable to find variscitebearing veinlets (gray shales) and which were not (brown and multicoloured shales). We have found no evidence that the miners dug indiscriminately into the country rocks. On the contrary, they acquired some basic knowledge about the local geology, gathered original ideas about what to look for (and where) to obtain variscite for ornaments, and applied their observations as a consistent tool for their routine at work.

\section{Acknowledgements}

This work was initially financed by a First Prize in the Spanish Contest for Young Scientists in 1992, granted by the Spanish Government, by a First Prize in the European Union Contest for Young Scientists in 1993, granted by the XII Direction of the European Commission, and by the DGCYT research grant AMB94-0953-CO2-01. Our study benefited initially from the collaboration of Albert Arcas, Gabriel Sáez and, specially, from Maria-Cinta Salvany. The EPM, SEM and XRD analyses were done in the Serveis Cientificotècnics of the Universitat de Barcelona, with the collaboration of Xavier Llovet, Javier García Veigas, Ramon Fontarnau, Xavier Alcobé and Josep Bassa. The Museu de Gavà facilitated our access to the mines at any time.

\section{References}

Alfonso, M.P., Canet, C., Melgarejo, J.C. and Fallick, A.E., 2002, Sulphur isotope composition of Silurian shale-hosted PGE-Ag-Au-Zn-Cu mineralisations of the Prades Mountains (Catalonia, Spain): Mineral. Dep., 37 198-212.

Alonso, M., Edo, M., Gordo, L., Millán, M. and Villalba, M.J., 1978 , Explotación minera neolítica en Can Tintoré (Gavà, Barcelona): Pyrenae, 13-14, 7-14 (in Spanish).

Bednarik, R.G., 1992, Early Subterranean Chert Mining: Artefact, 15, 11-24.

Bosch, J., Carreté, J.M., Estrada, A. and Verdaguer, T., 1993, El neolític antic evolucionat a les mines prehistòriques de Gavà: noves aportacions del projecte mines prehistòriques. - Pyrenae, 24, 57-77 (in Catalan).

Bosch, P.W., 1979, A Neolithic flint mine: Sci. Am., 240/6, 126-132.

Bostyn, F. and Lanchon, Y., 1992, Jablines le Haut Ch,teau (Seine et Marne): une minière de silex au Néolithique: Doc. Archeol. Fr., 35, 246 p. (in French).

Camprubí, A., Costa, F., Salvany, M.C., S.ez, G., Arcas, A. and Melgarejo, J.C., 1993a, Las mineralizaciones de fosfatos alumínicos en la Serra de Miramar, Catalunya: Bol. Soc. Esp. Mineral., 16/1, 55-56 (in Spanish).

Camprubí, A., Costa, F., Salvany, M.C., S.ez, G. and Arcas, A., 1993b, Las minas neolìticas de fosfatos de Gavà (Catalunya). Unpublished document, Universitat de Barcelona, 63 p. (in Spanish).

Camprubí, A., Costa, F. and Melgarejo, J.C., 1994, Mineralizaciones de fosfatos fÈrrico-alumínicos de Gavà (Catalunya): tipología: Bol. Geol. Min., 105/5, 444-453 (in Spanish). 
Costa, F., Camprubí, A., Salvany, M.C., Sáez, G., Arcas, A. and Melgarejo, J.C., 1993, The phosphate mineralizations from Gavà, Catalonia, Spain. In F. Gervilla, P. Fenoll, J. Torres (eds.), Current Research in Geology Applied to Ore Deposits, 1, 715-718.

Costa, F., Camprubí, A. and Melgarejo, J.C., 1994, Aproximación geológica a las minas neolíticas de fosfatos férrico-alumínicos de Gavà (Catalunya): Bol. Geol. Min., 105/5, 436-443 (in Spanish).

Dart, R.A. and Beaumont, P., 1967. Amazing Antiquity of Mining in Southern Africa: Nature, 216, 407-408.

Dill, H.G., Busch, K. and Blum, N., 1991, Chemistry and origin of vein-like phosphate mineralization, Nuba Mountains (Sudan): Ore Geol. Rev., 6, 924.

Fernández-Turiel, J.L., Gimeno, D., Plana, F., Blasco, A., Edo, M. and Villalba, M.J., 1990, Estudio de las mineralizaciones fosf.ticas del complejo minero de Can Tintorer (Gavà, Barcelona) y comparación con las cuentas procedentes de ajuares arqueológicos: Bol. Soc. Esp. Mineral., 13/1, 8687 (in Spanish).

Galiberti, A., Di Lernia, S., Fiorentino, G. and Guarascio, M. , 1991, New data about the Neolithic mine of the Defensola (Puglia, Italy): VI International Flint Symposium, 145-148.

Haas, J. and H·mor, G., 2002, Geological garden in the neighborhood of Budapest, Hungary: Episodes, 24/4, 257-261.

Julivert, M. and Duran, H., 1990, Paleozoic stratigraphy of the Central and Northern part of the Catalonian Coastal Ranges (NE Spain): Acta Geol. Hisp., 25/1-2, 3-12.

Melgarejo, J.C., 1992, Estudio geológico y metalogenético del Paleozoico del sur de las Cordilleras Costeras Catalanas: Memorias Instituto TecnolÛgico Geominero de España, 103, 605 p. (in Spanish).

Melgarejo, J.C., Jorge, S., Taylor, R.P. and Jones, P., 1994, The occurrence of platinum group and Au-Ag-V-Cr-REE minerals in Lower Silurian sedimentary-exhalative (SEDEX) sulphide mineralization, Poblet, Catalonia,

Antoni Camprubi graduated in geology in 1994. During his graduate studies, he takes part with other students in the development of a research on the Neolithic Mines of Gavà. This study obtained the first prize in the European Union Contest for Young Scientists in 1993. He got his Ph.D. degree at the University of Barcelona in 1998. He is currently a full time researcher at the Centro de Geociencias, Campus UNAMJuriquilla (Mexico). His interests include fluid inclusions and isotope geochemistry and metallogenesis (epithermal, skarn and MVT deposits).

Joan Carles Melgarejo got his doctor in Geology at University of Barcelona in 1987 and is Associate professor of Mineralogy at this university since 1988. He is working in several projects in Mineralogy and Ore Deposit Modeling. Some of his recent research subjects include pegmatites in Catalonia and Mexico, sedex deposits in Catalonia and Cuba, VMS, manganese deposits, podiform chromitites and laterites in Cuba, and present-day formed submarine exhalative deposits in Mexico. Adviser for the Strategic Plan of Mining in Catalonia 2000-2010 (Generalitat de Catalunya), he also study historical aspects of mining in Catalonia.

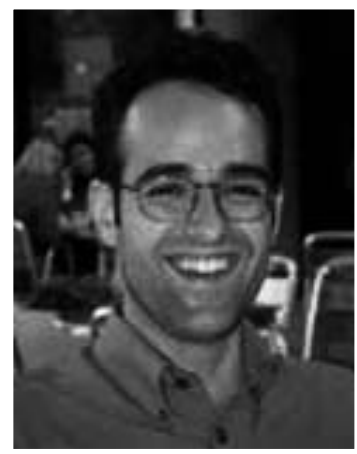

Joaquín A. Proenza graduated in geology in 1992. He got his Ph.D. degree at the University of Barcelona (1998). He is Assistant Professor at the Departament de Cristal-lografia, Mineralogia $i$ Dipòsits Minerals of the Barcelona University. His research activities are concerned with mineralogy, petrology and metallogenesis (mainly chromite deposits and laterites) of ophiolite complexes in Cuba, Mexico, Argentina, Colombia and Dominican Republic.

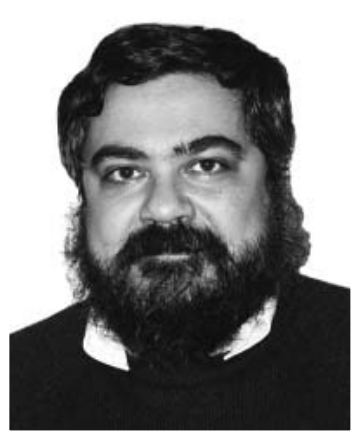

Josep Bosch Argilagós is garduated in archaeology at the University of Barcelona, Faculty of Geography and History, Department de Prehistòria Antiga i Arqueologia. His research subject is the Neolithic period, and the origin of the Neolithic in the Western Mediterranean domain. He directed several archaeological excavations, mainly in Catalonia. Since 1992, he is the curator of the Cavà Museum (Barcelona), and the director of the rchaeological excavations in the arcgaeological site of the Mines Prehistoòriques de Gavà.
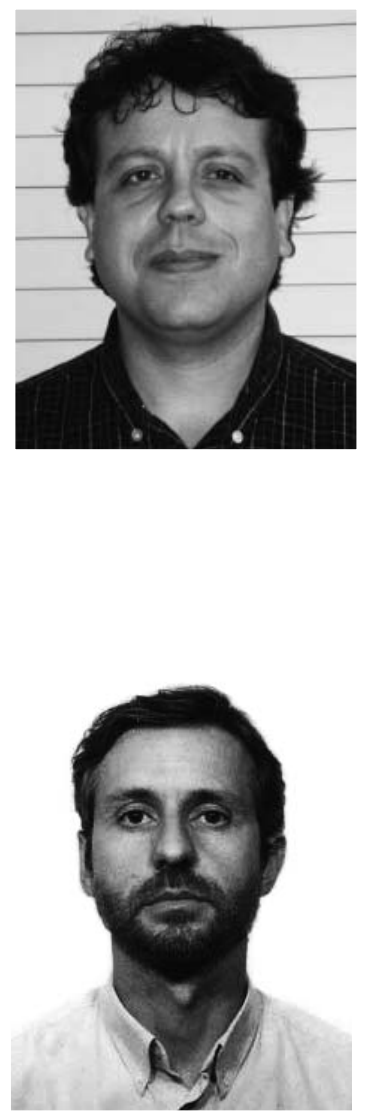